\title{
Atmospheric and Sea-Ice Conditions in the Northwest Atlantic During the Decade, 1991-2000
}

\author{
Kenneth F. Drinkwater ${ }^{1}$ \\ Fisheries and Oceans Canada, Bedford Institute of Oceanography \\ P. O. Box 1006, Dartmouth, Nova Scotia Canada B2Y 4A2
}

Drinkwater, K. F. 2004. Atmospheric and Sea-Ice Conditions in the Northwest Atlantic During the

Decade, 1991-2000 J. Northw. Atl. Fish. Sci., 34: 1-11. doi:10.2960/J.v34.m511

\begin{abstract}
Atmospheric and sea ice conditions within the Northwest Atlantic during the decade 1991-2000 are described. The NAO index in the 1990s was the highest in the past 11 decades and there has been a general increase from the minimum of the 1960s. The high NAO in the 1990s was accompanied by an increase in southwesterly winds in the Labrador Sea region. With the exception of Nuuk, mean decadal air temperatures were above their long-term means at selected sites throughout the NAFO area, including record high decadal means in the Gulf of St. Lawrence and at Cape Hatteras. Air temperatures have generally been increasing since the 1960s from the Scotian Shelf northward. Sea-ice conditions off the Labrador and northern Newfoundland coast, in the Gulf of St. Lawrence and the Scotian Shelf indicate the least amount of ice in the 1960s. From Labrador to the Gulf of St. Lawrence there was little difference in ice severity between the 1970s, 1980s and 1990s; however, on the Scotian Shelf the ice area was less during the 1990s compared to the previous two decades. The decadal mean of the number of icebergs drifting southeastward along the Labrador and Newfoundland shelves was at a maximum during the 1990s. There has been large intra-decadal variability in all climate indices examined. The early years of the 1990 s were characterized by high NAO indices, strong northwesterly winds, cold air temperatures from the Labrador Sea to the Gulf of Maine, and extensive ice cover. In 1996, the NAO index experienced its largest annual decline in the over 100-year record. During the remaining years of the 1990s decade, the NAO rose achieving values that even exceeded those of the early years of the 1990s. Of significance during the latter half of the decade was the eastward shift in the center of the atmospheric low-pressure system over the Northwest Atlantic. This shift contributed to weaker northwesterly winds, warmer temperatures in the Labrador Sea to the Gulf of Maine, and a reduction in sea-ice.
\end{abstract}

Key words: 1990s, climate, icebergs, sea-ice, temperatures, NAO, pressure, wind

\section{Introduction}

The atmospheric and sea ice conditions in the NAFO area of the Northwest Atlantic are known to undergo variability over a range of time scales from days to centuries. The largest variance typically is at the annual cycle. For example, it accounts for $>85 \%$ of the total variability in the time series of monthly mean air temperatures. Although smaller than the annual cycle, there still is significant variance at time scales from greater than one year to tens of years.

While there is nothing special in nature about multiples of 10, decadal reviews of climate conditions or progress within a certain field is common. NAFO has a long tradition of decadal or near decadal reviews, beginning with a review of the 1950s. While it is useful to regularly review environment conditions in an attempt to synthesize events and to clarify our thinking, it must be remembered that many of the climate trends and processes have much longer time scales than the 10 -year periods.

This paper examines meteorological (air pressures, winds, air temperatures) and sea-ice conditions in the Northwest Atlantic (Fig. 1) during the period 1991-2000, hereafter referred to as the 1990 s. It compares this decade to conditions during previous decades and discusses intradecadal variability.

\section{Data and Methods}

The meteorological variables examined include air pressures and the related North Atlantic Oscillation (NAO) index, winds and air temperatures for most of the NAFO Convention Area. The sea-ice conditions are restricted to the Labrador and Newfoundland shelves as

1 Present Address: Institute of Marine Research, P. O. Box 1870 Nordnes, N-5817 Bergen, Norway. 


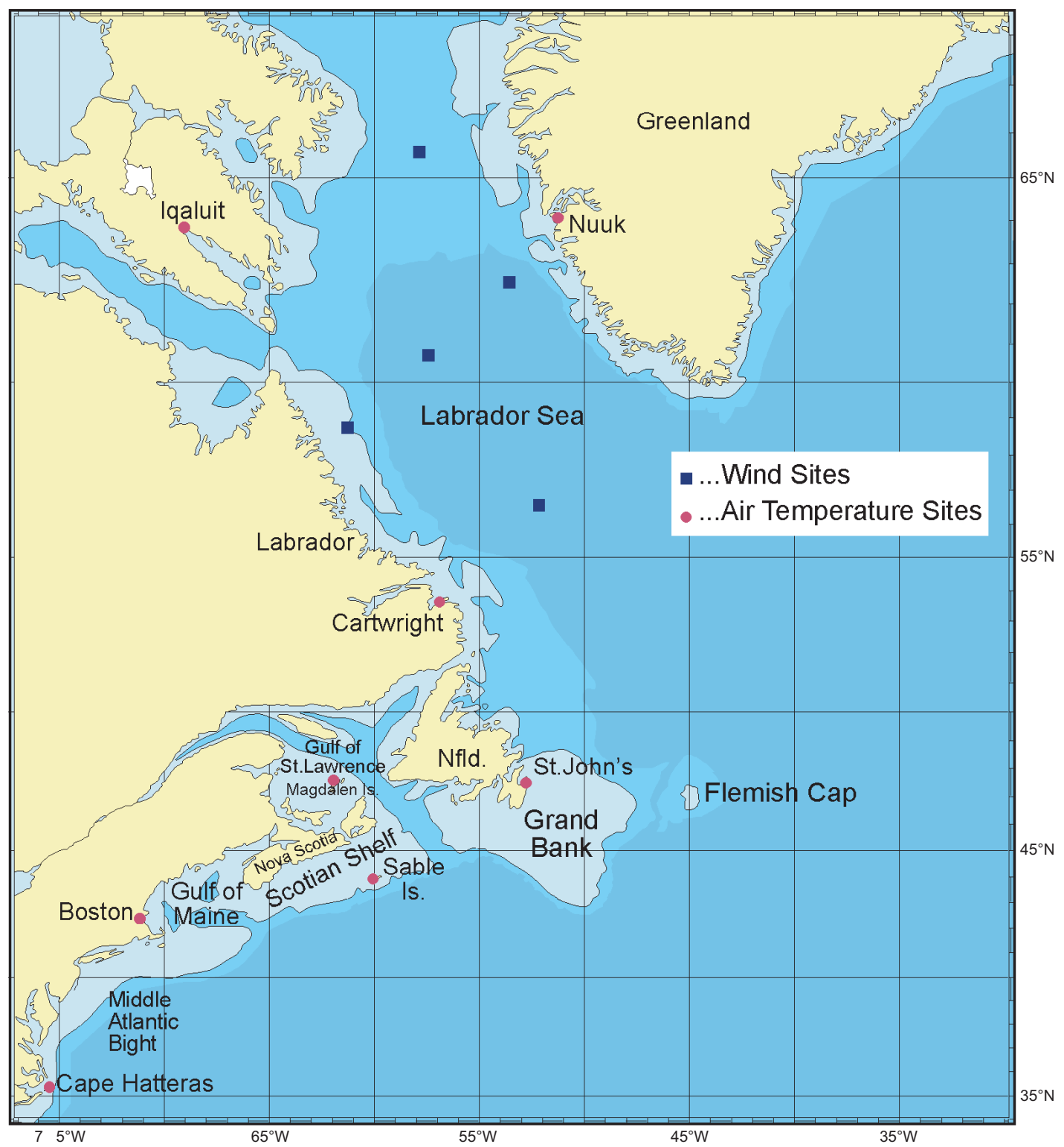

Fig. 1. The map of the Northwest Atlantic showing the study area including air temperature sites and Labrador Sea wind sites.

well as the Gulf of St. Lawrence and the Scotian Shelf (NAFO Subareas 2 through 4) and include ice area and numbers of icebergs.

Monthly sea level pressure data throughout the North Atlantic are from the German Weather Service's monthly publication Grosswetterlagen Europas. The annual NAO index is derived from the average of the monthly mean sea level pressures during the winter (December to February) at Ponta Delgada (up to 1997) or Santa Maria (since 1997) in the Azores minus those at Akureyri in Iceland. The pressure data are published in the National Oceanographic and Atmospheric Administration (NOAA) publication Monthly Climatic Data for the World. The small number of missing data early in the time series was filled using pressures from nearby stations. The NCEP (National Centre for Environmental Prediction) - NCAR (National Center for Atmospheric Research) reanalysis of winds were obtained from the International Research Institute of the Lamont-Doherty Earth Observatory at Columbia University. Details on the reanalysis of winds can be found in Kistler et al. (2001). 
Air temperature data were obtained for eight representative stations throughout the Northwest Atlantic including Nuuk in Greenland, Iqaluit on southern Baffin Island, Cartwright on the southern Labrador Coast, St. John's in eastern Newfoundland, the Magdalen Islands in the central Gulf of St. Lawrence, Sable Island on the Scotian Shelf off Nova Scotia, Boston in the southern Gulf of Maine and Cape Hatteras at the southern tip of the Middle Atlantic Bight (Fig. 1). The monthly means from the Canadian sites were taken from the Environment Canada website (http://www.msc-smc.ec.gc.ca/climate/ products_services/climate_products/climate_summaries e.cfm) and for non-Canadian locations from the National Climate Data Center of the U.S. National Oceanic and Atmospheric Administration (NOAA) publication Monthly Climatic Data for the World.

Information on the location and concentration of sea ice is available from the daily ice charts published by Ice Service of Environment Canada in Ottawa. These daily charts are digitized onto a grid $0.5^{\circ}$ latitude by $1^{\circ}$ longitude for Newfoundland and southern Labrador (Peterson and Prinsenberg, 1990), the Gulf of St. Lawrence and the Scotian Shelf (Drinkwater et al., 1999). These databases contain data beginning in the early-1960s and continue to the present. The U.S. Coast Guard publishes the number of icebergs that cross southward of $48^{\circ} \mathrm{N}$ by month. This latitude approximately delineates the northern edge of the Grand Banks.
Climate anomalies were calculated by subtracting the 1971-2000 mean, unless otherwise stated. In the case of sea-ice, only data during those years ice was present were used in the calculation of the long-term mean ice coverage.

\section{Results}

\section{Air Pressure Patterns and The North Atlantic Oscillation (NAO)}

The Icelandic Low, centered between southern Greenland and Iceland, and the Azores High, centered roughly above the Azores dominate the large-scale atmospheric pressure patterns over the North Atlantic Ocean (Fig. 2). The High and Low occur year round but are most intense in winter. Their strengths vary year-to-year with a tendency for both pressure systems to intensify (or weaken) in the same year. This is known as the NAO. It is the most robust of all of the recurrent modes of atmospheric behaviour in the world being present in all months of the year (Barnston and Livezey, 1987). Rogers (1984) defined an NAO index based upon the difference in the average pressure during December, January and February between Iceland and the Azores. Later, Hurrell (1995) used pressure differences between Iceland and Lisbon in Portugal (December through March) in order to extend the data series further back in time. A high NAO index (positive phase) occurs when the pressure systems strengthen and a low index (negative phase) when they weaken. The NAO

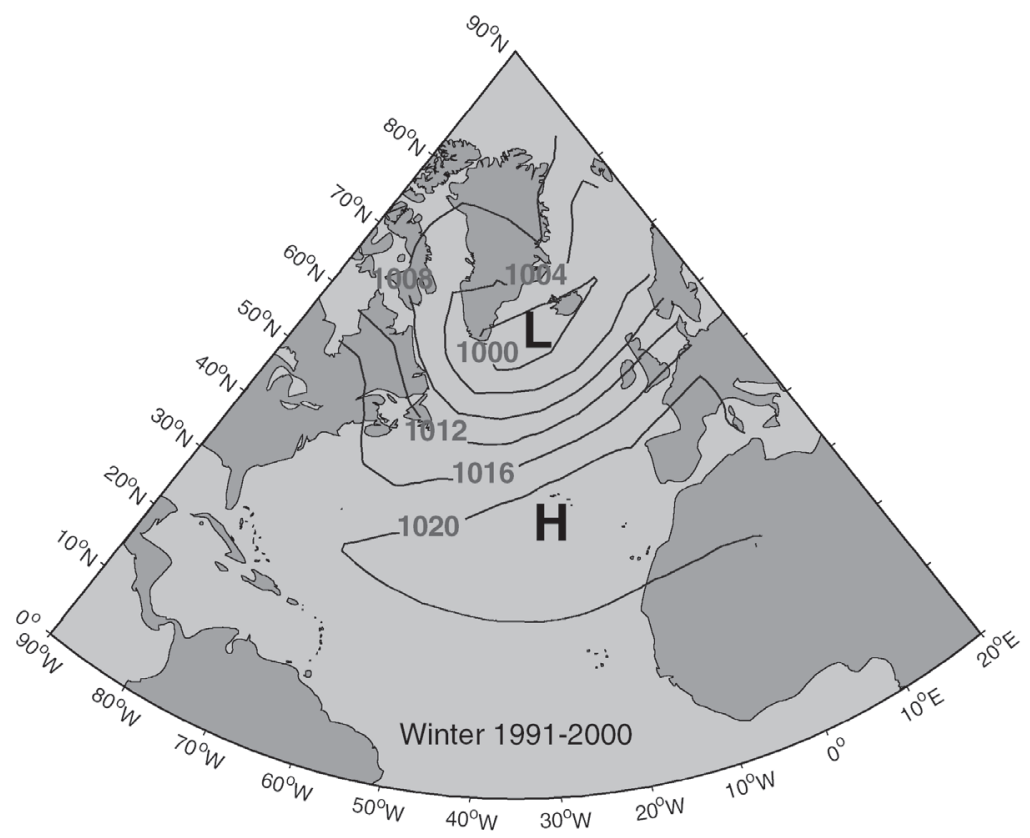

Fig. 2. The winter sea level pressure field over the North Atlantic Ocean averaged over 1991-2000 showing the Icelandic Low (L) and the Azores High (H). 
index varies greatly from year-to-year but with discernible longer period trends. The index, which is a latitudinal pressure gradient, reflects the strength of the westerly winds across the northern North Atlantic. Generally, it also means stronger northwest winds over the Labrador Sea (Drinkwater, 1996). In such years, these northwest winds carry cold Arctic air masses further south causing winter air temperatures to decrease resulting in greater formation of sea ice (Colbourne et al., 1994; Drinkwater, 1996).

The mean winter (December, January and February) air pressure over the North Atlantic for the 1990s reveals the presence of the Icelandic Low and the Azores High (Fig. 2). Relative to the previous 9 decades, the NAO index in the 1990s was the highest on record and had climbed steadily from the minimum of the 1960s (Fig. 3A). This is indicative of an increase in the intensity of the largescale atmospheric circulation over the North Atlantic Ocean during the winter. Within the decade of the 1990s, the index was relatively high in the early years (Fig. 3B). In 1996, however, it declined rapidly from the previous year's high positive anomaly to a large negative anomaly as the Icelandic Low and Azores High weakened. This was the largest annual decline in the NAO index in it's over 100-year record. After 1996, the index rose steadily as the pressure systems intensified. By the late-1990s, the index had returned to values equivalent to those recorded in the early years of the decade. In spite of these changes, the within decade variability of the NAO during the 1990s as measured by the standard deviation was slightly lower than had been observed in each of the previous three decades (Fig. 3C).

In addition to the temporal changes in the index, a significant eastward shift in the spatial pattern of the anomalous pressure patterns occurred after 1995. The centers of the anomalous pressures moved to the northeastern sector of the North Atlantic. This had important ramifications on conditions in the Northwest Atlantic. With the eastward shift of the Icelandic Low, the pressure gradients in the northwest declined and with it the strength of the correlations between the NAO and atmospheric and sea ice conditions.

\section{Winds}

Winds are important in driving ocean currents and ice drift, promoting heat exchange between the atmosphere and the ocean, and causing vertical mixing of the water column. They are also related to the air pressure fields through geostrophy, i.e. winds tend to blow perpendicular to the pressure gradients with the high pressure on the right looking downwind. Thus, winds move clockwise around the Azores High and counterclockwise around the Icelandic Low.
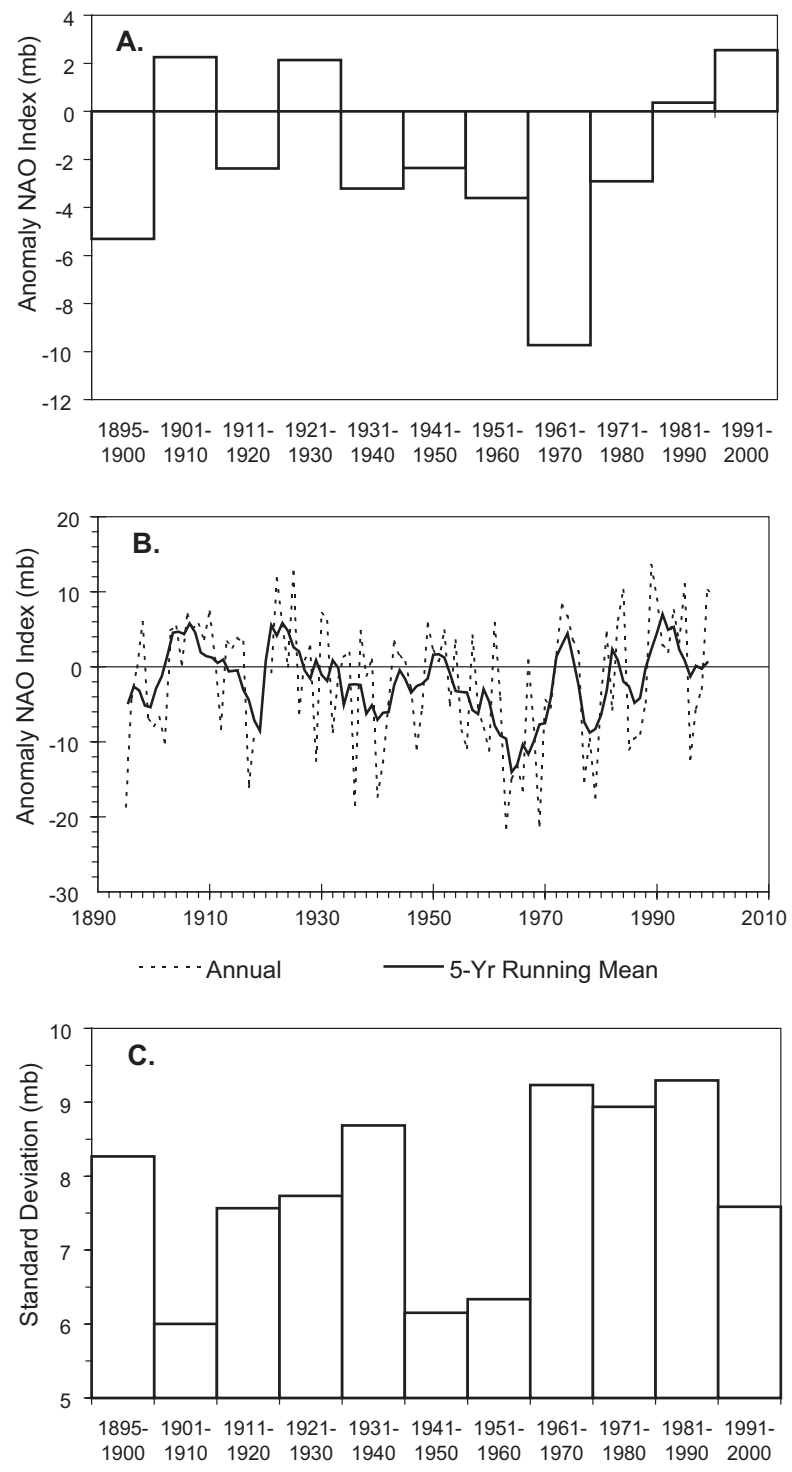

Fig. 3. (A) The decadal anomalies, (B) the annual and 5-year running mean of the anomalies and $(\mathbf{C})$ the within decade standard deviations of the NAO Index in mb.

Seasonally, winter winds tend to be the most intense. They determine the extent of the winter mixing in the ocean, including the depth of convection in the Labrador Sea. During the 1990s, the winter winds in the northern Labrador Sea and in the Gulf of Maine and southwestern Scotian Shelf were predominantly northwesterly (Fig. 4). Elsewhere, the winter winds were shifted more westerly. Relative to the previous four decades, winter winds throughout the region were generally more westerly in the 1990s (Fig. 5).

Five locations were chosen to represent winds over the Labrador Sea. These included sites in central Davis Strait, central Labrador Sea, the southern entrance to the 


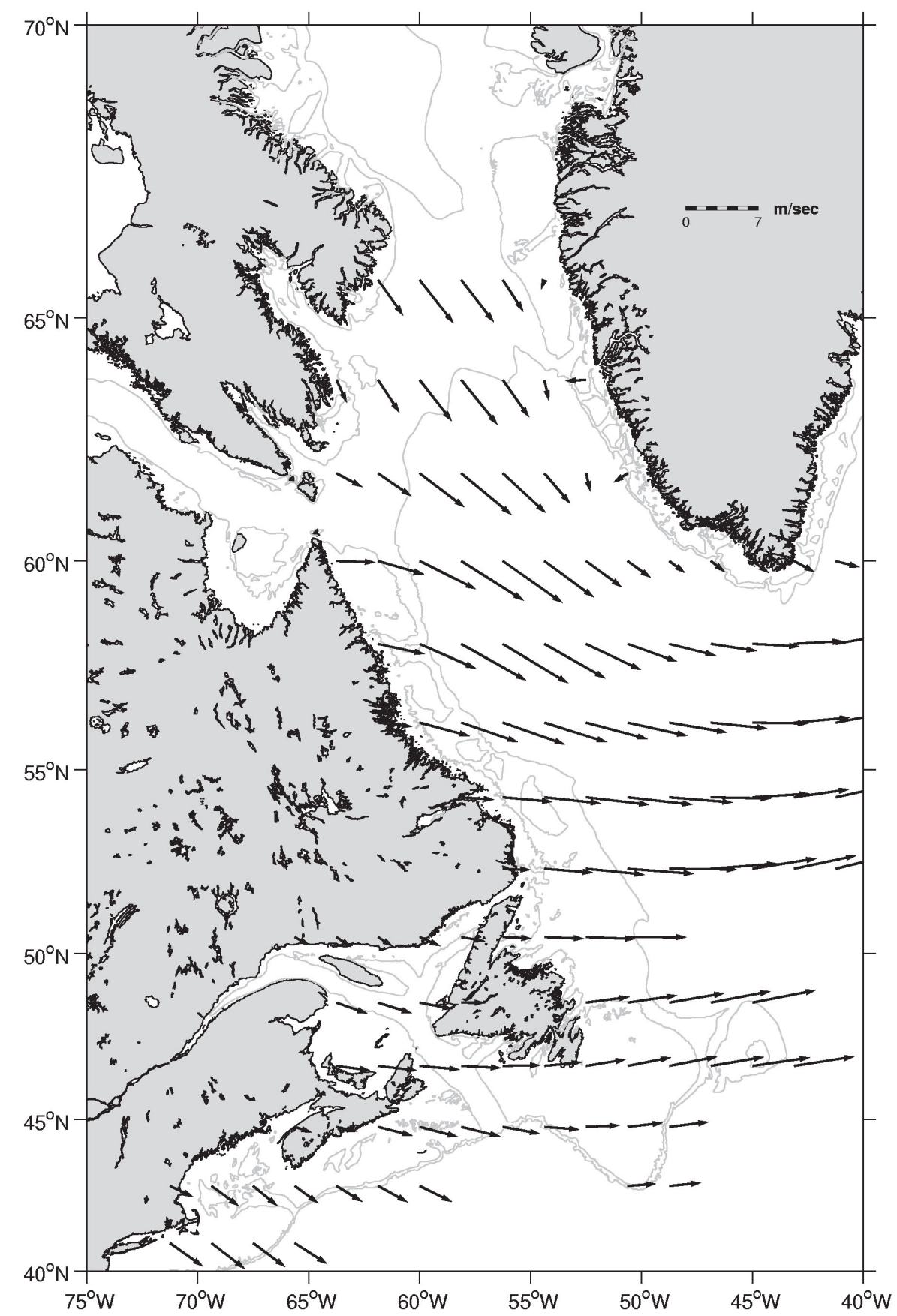

Fig. 4. The mean winter winds during the 1990s.

Labrador Sea, one off the mid-Labrador Coast and another south of Fyllas Bank on the West Greenland side (Fig. 1). A time series of winter winds was developed by averaging the wind components observed at these 5 sites. The resultant winds were resolved along 315 and 45 degrees from north, which lie approximately along and across the axis of the Labrador Sea, respectively. The predominant winds are from the northwest with a long-term mean wind speed near $4 \mathrm{~ms}^{-1}$ (Fig. 6A). These show near equal decadal means for all decades except the 1960s when it was below $3 \mathrm{~ms}^{-1}$. The largest change came in the crosssea component where the southwesterly wind component increased steadily from the 1960 s from near zero to 1.5 $\mathrm{ms}^{-1}$ by the 1990s (Fig. 6B). 

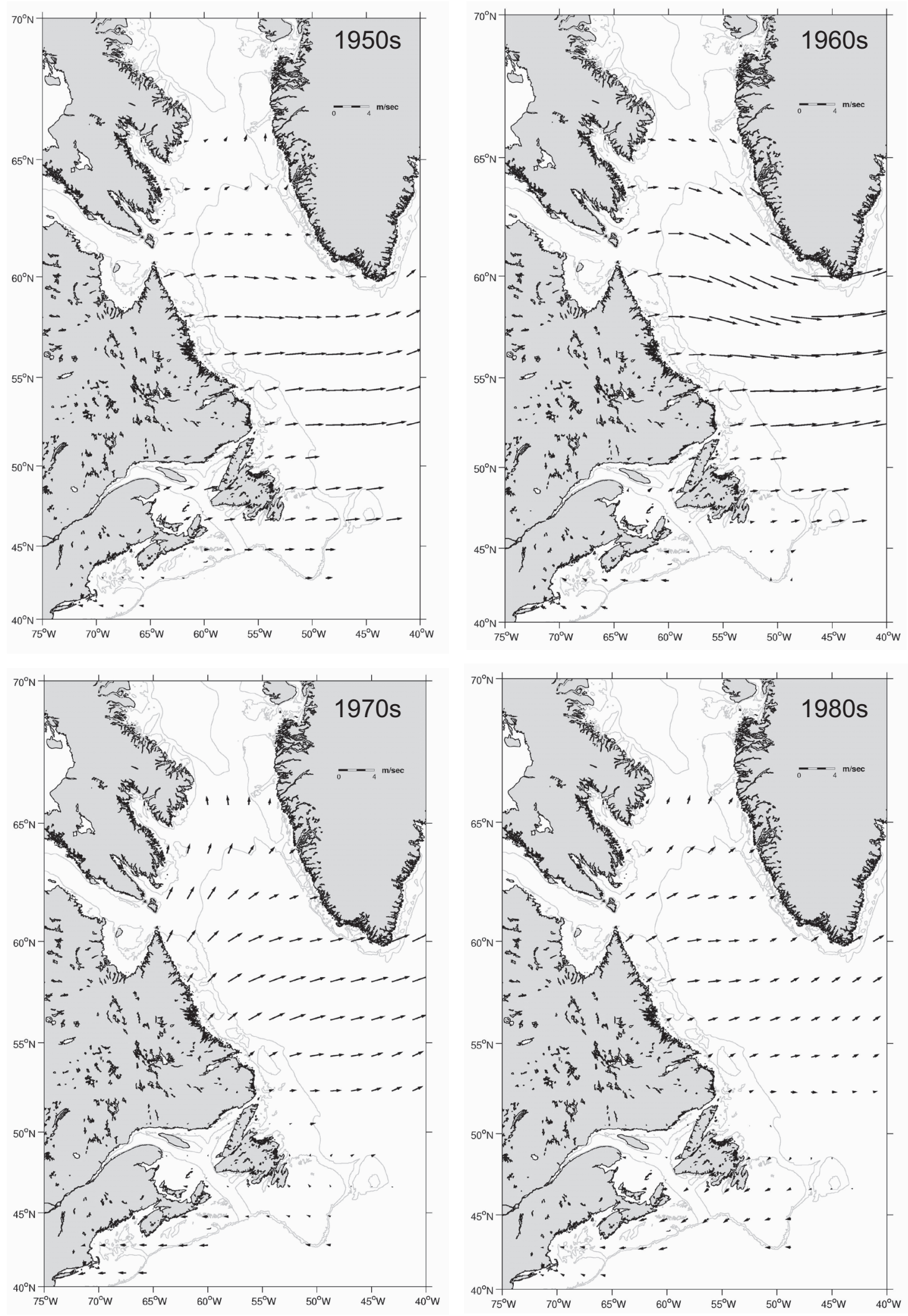

Fig. 5. The difference in mean winds between the 1990s and the previous decades; the 1950s (upper left), the 1960s (upper right), the 1970s (lower left) and the 1980s (lower right). 

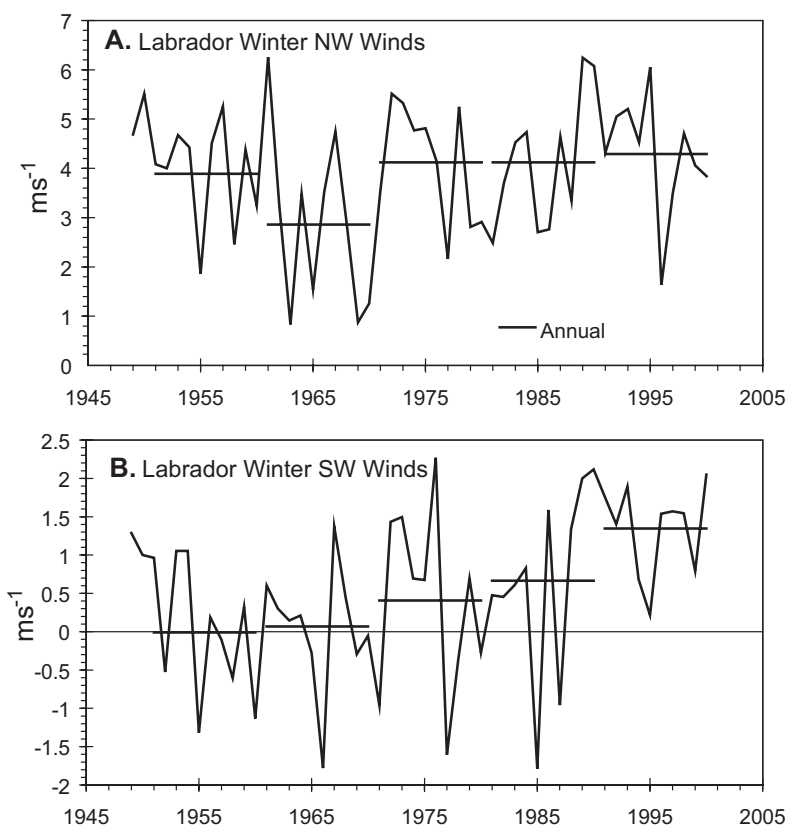

Fig. 6. The strength of the annual mean winter northwesterly (A) and southeasterly winds (B) for the Labrador Sea. In (A) positive represents northwesterly winds while in (B) it represents southwesterly winds and negative represents northeasterly winds. The horizontal lines indicate the decadal means.

Again, however, the decadal means hide significant intra-decadal variability (Fig. 6). The northwesterly winds were stronger during the early years of the 1990s, declined dramatically in 1996 when the NAO also declined significantly and then rose in the later years of the 1990s, but never recovering to the levels of the early part of the decade. The similarity of the winds with the NAO is consistent with earlier periods with approximately $50 \%$ of the variance in the winter northwesterly winds being accounted for by the NAO (Fig. 7A). For the cross-sea component, the winter winds throughout the decade were southwesterly. They were of higher magnitude in the early years of the decade, declined in the middle years and rose again towards the end. Although the NAO also accounts for some of the variability in the cross-sea component of the wind stress (30\%), it is less than for the along-sea component (Fig. 7B).

\section{Air temperatures}

Annual air temperatures were selected at eight sites throughout the NAFO area (Fig. 1). Decadal means at the eight sites show several interesting features. First, the 1990s were above the 1971-2000 mean at all sites except for Nuuk (Fig. 8). The amplitude of the anomalies was between $0^{\circ}$ and $0.5^{\circ} \mathrm{C}$. At two sites, the Magdalen
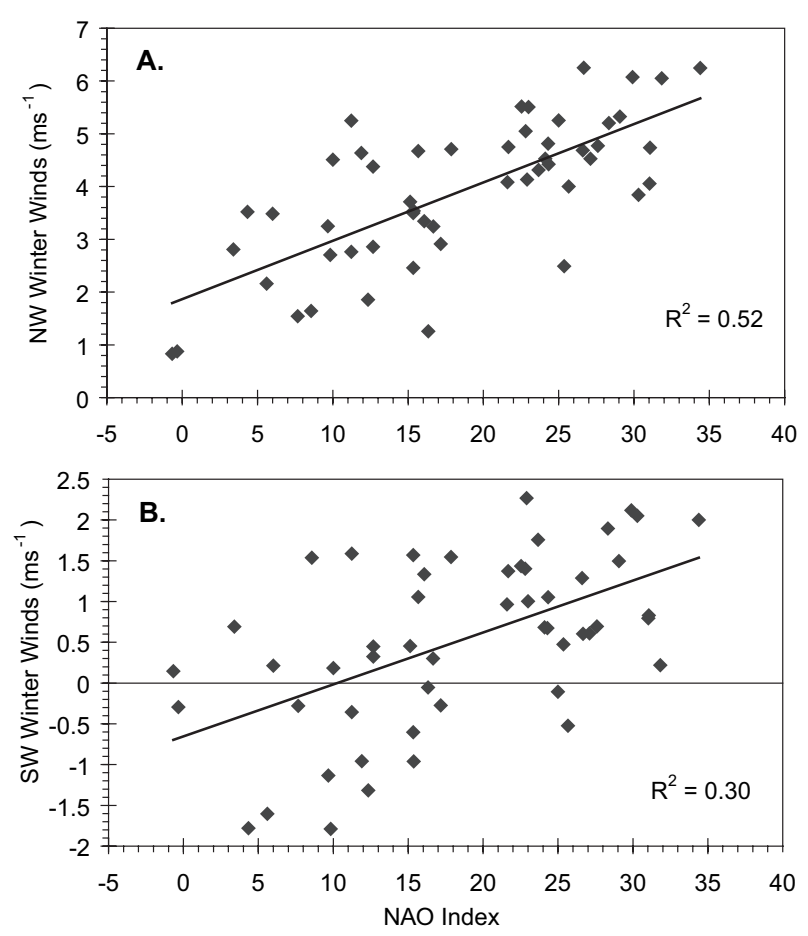

Fig. 7. The relationship of the NAO index with the northwesterly (A) and the southwestly (B) wind components in the Labrador Sea. Note that in (A) the northwesterly winds are defined as positive while in (B) positive indicates southwesterly winds and negative northeasterly winds.

Islands and Cape Hatteras, the 1990s set decadal highs. In the case of the latter, the time series spans 13 decades. The decadal means show the consistent cold period in the 1800 s and into the first few decades of the 1900s in the southern sites. Also, the dramatic warming in the northern North Atlantic during the 1920s and 1930s are evident at Nuuk and follow later at several of the other northern sites (Iqaluit and Cartwright). Since the 1970s there has been a trend towards increasing temperatures at all sites.

The within decade variability during the 1990s differs between sites. At most sites the early part of the decade experienced cold conditions but warmed substantially towards the latter half(Fig. 9). During 1999, historic high annual means were observed from southern Labrador to the Gulf of Maine and significantly higher at some sites such as the Magdalen Islands. At the southern sites, this trend reverses and at Cape Hatteras, for example, the annual air temperatures were highest in the early years of the 1990s and declined through to the later years (Fig. 9). The year 1999 experienced below normal air temperatures at Cape Hatteras, in contrast to the historic highs of some of the northern sites. 


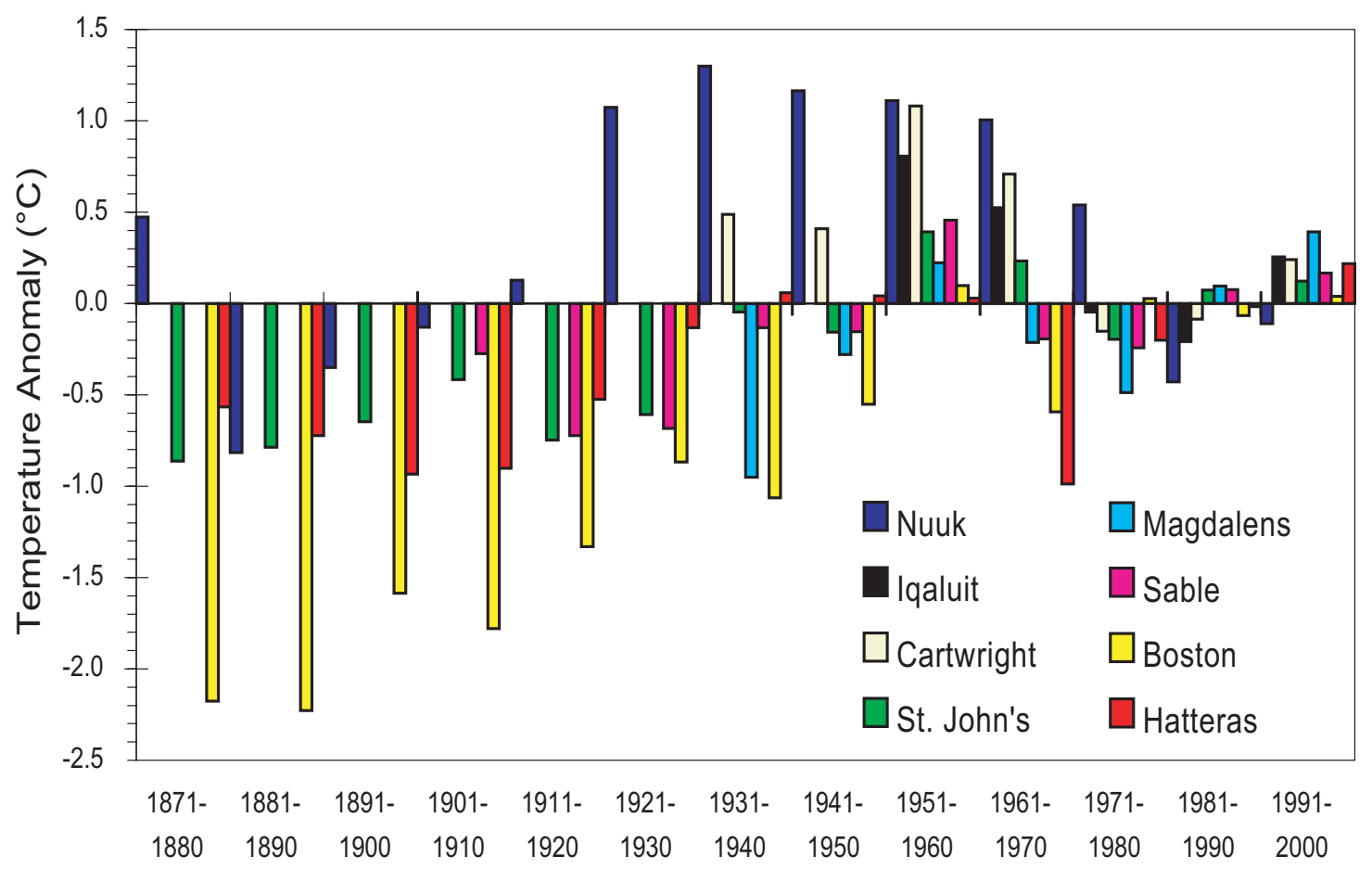

Fig. 8. The decadal means of the temperature anomalies for the 8 selected air temperature sites (see Fig. 1 for locations).

\section{Sea Ice}

Newfoundland. The monthly mean areal extent of sea ice on the Newfoundland Shelf south of $55^{\circ} \mathrm{N}$ was determined for each decade from the 1960s when the records began. These show that the 1990s were similar to the 1970s and 1980s but were well above the 1960s (Fig. 10). The ice area during the 1960s was approximately one-half the size of those in the other decades. In addition, the ice formed later and left earlier during the 1960s. As with the air temperatures and winds, the decadal means mask large intra-decadal variability (Fig. 10). The mean annual ice area (averaged from December of the previous year to June) was most extensive during the early years of the 1990s but declined to relative low levels in the latter half of the decade. These are consistent with the air temperatures and local winds, with cold temperatures and stronger northwesterly winds accompanying years of greater ice extent and warmer temperatures and weaker northwesterly winds during years of smaller sea ice extent. The time series is dominated by peaks in the early-1970s, 1980s and 1990s, which also correspond to periods of coldest temperatures and strongest northwest winds in winter.

Gulf of St. Lawrence. Although the total area of the Gulf of St. Lawrence is much smaller than the Newfound- land Shelf, sea ice within the Gulf exhibits a temporal pattern similar to that seen in Newfoundland waters. The 1960s again stand out compared to the other decades, being a time when there was much less ice (Fig. 11). The 1990 s were slightly more distinguishable from the 1970s and 1980s than off Newfoundland, being later in forming than during the other two decades. The within-decade variability also shows similarity with Newfoundland, with the maximum ice extent during the decade occurring in the early years of the 1990s and declining to relatively low levels in the latter half of the decade (Fig. 11). The latter were years of the lowest amount of sea ice in the Gulf since the 1960s. The peak ice extent occurred in the early-1970s and between the late-1980s and early-1990s. The annual mean ice area was determined from the average of December of the previous year to May.

Scotian Shelf. The area of sea ice, seaward of Cabot Strait, also shows the lowest values during the decade of the 1960s (Fig. 12). However, unlike Newfoundland and the Gulf, there was much less sea ice during the 1990s than in the 1970s and 1980s. Although the total area of sea-ice is much less than off Newfoundland and in the Gulf of St. Lawrence, the relative variability in extent is much larger. This is perhaps not surprising given that the Scotian Shelf is at the southern limit of sea ice in the western North Atlantic and will depend much more upon advection 

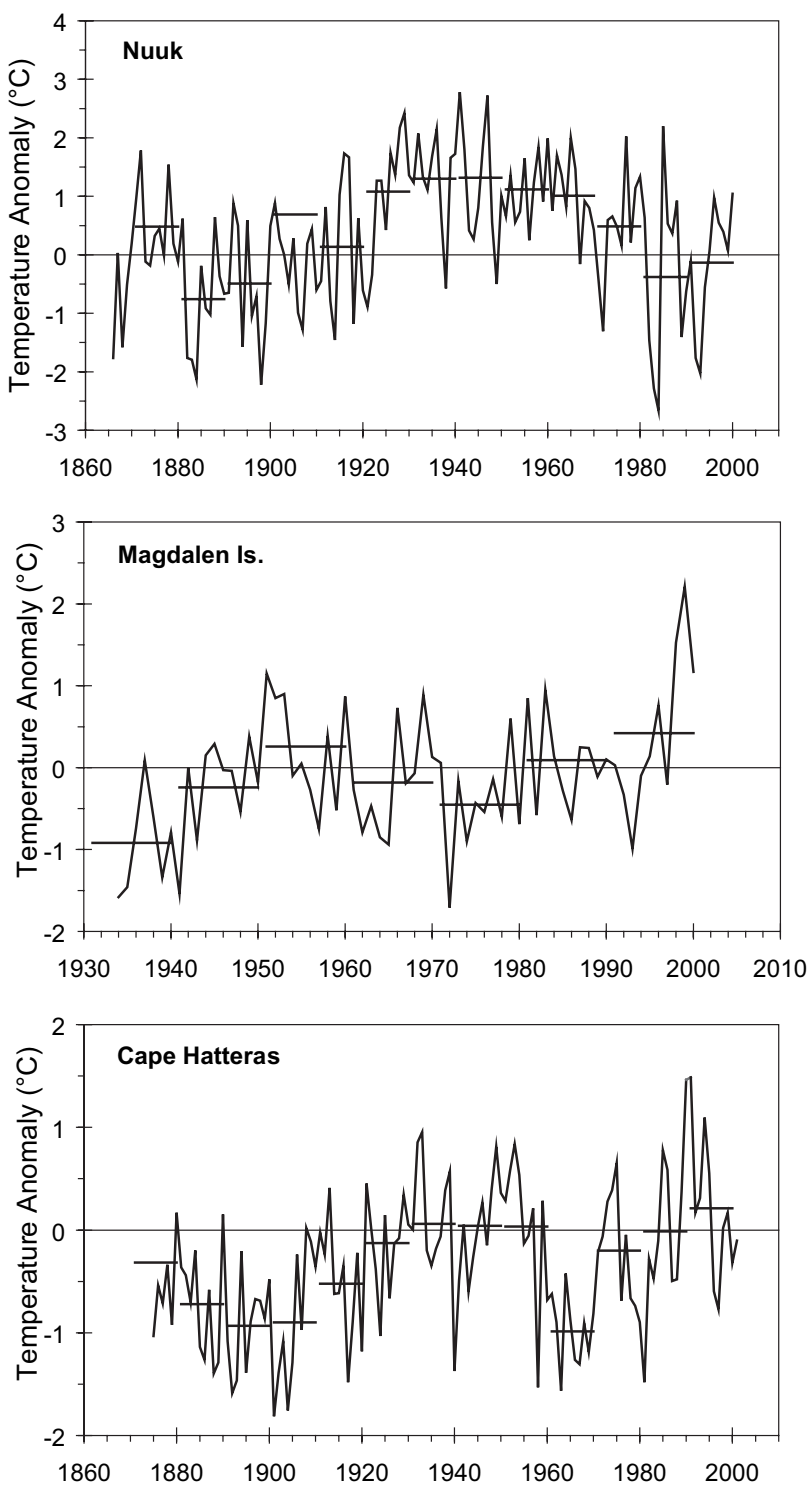

Fig. 9. The annual mean air temperature anomalies from Nuuk, Magdalen Islands and Cape Hatteras. The horizontal lines represent the decadal means.

from the north than local ice formation. The amount of ice advected onto the Shelf depends upon wind strength and direction, as well as the ocean currents. The rate of melting will depend upon both the ocean and air temperatures, and wind-induced waves that will tend to break up the ice. Similar to Newfoundland and the Gulf, however, the largest areal extent of ice (averaged over January to April) on the Scotian Shelf was during the early years of the 1990s and then declined to relatively low values in the latter half of the decade. These latter years have been the longest extended period of reduced ice extent since the 1960s.
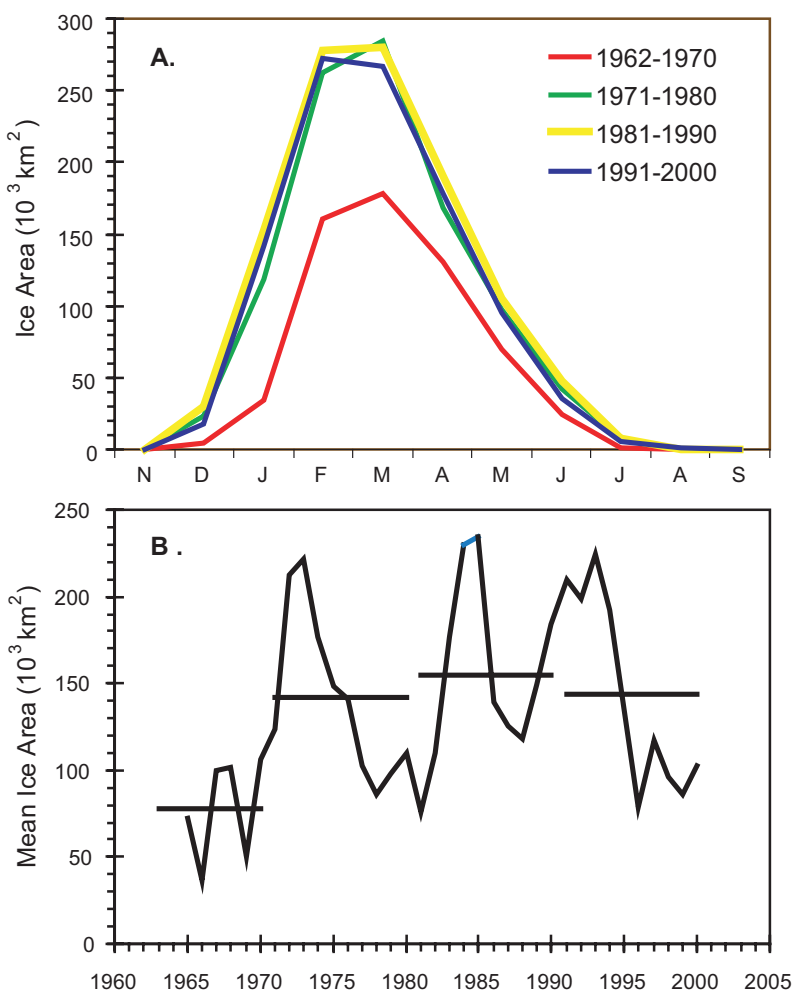

Fig. 10. (A) The monthly mean ice area averaged by decade and (B) the time series of the annual mean ice area based upon the average of the monthly values from December (of the previous year) to June for the Labrador and Newfoundland shelves. The black horizontal lines represent the decadal means.

\section{Icebergs}

The number of icebergs that have been observed to cross south of $48^{\circ} \mathrm{N}$ on the eastern Newfoundland Shelf has been recorded since the late-1800s. The decadal means of the numbers that cross during the months March through July, which typically is $95 \%$ of the total number of icebergs that cross $48^{\circ} \mathrm{N}$, reveal relatively equal numbers from the late-1800s until the 1950s (Fig. 13). During that decade and the 1960s, the number of icebergs declined but then increased steadily through to the maximum number in the 1990s. Indeed, the average number of icebergs increased by almost a factor of two from the 1980s to the 1990s. Within the decade of the 1990s the iceberg numbers fluctuated interannually but with a general decreasing trend (Fig. 13). The numbers in 1999, which was the warmest year on record in the southern Labrador and Newfoundland area, were the lowest since 1980.

\section{Summary}

This paper has described the meteorological and seaice conditions in the Northwest Atlantic, with emphasis 

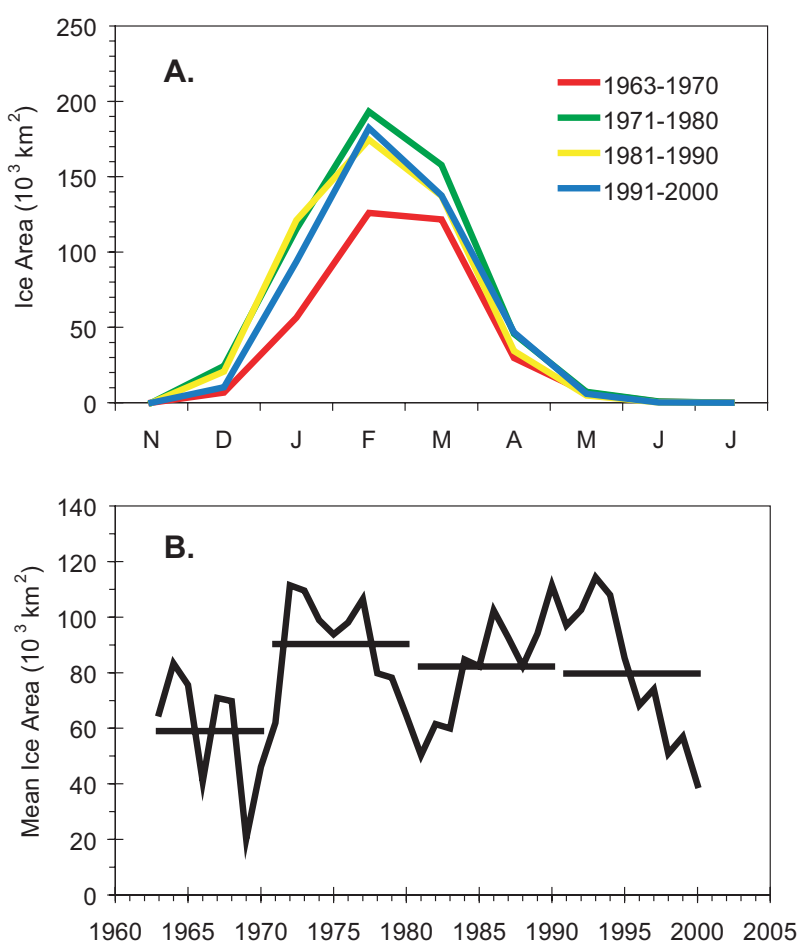

Fig. 11. (A) The monthly mean ice area averaged by decade and (B) the time series of the annual mean ice area based upon the average of the monthly means from December (of the previous year) to May for the Gulf of St. Lawrence. The black horizontal lines represent the decadal means.

upon the period 1991-2000. Decadal means were used to compare conditions during this period with past decades. The NAO index in the 1990s was the highest in the past 11 decades and there has been a general increase in the NAO index from the minimum of the 1960s. The high in the 1990s indicates a stronger atmospheric circulation with an intensified Icelandic Low and Azores High. While there was little change in the strength of the northwesterly wind component over the Labrador Sea during the 1990s compared to most recent decades, there was a significant increase in the southwesterly wind component. However, the northwest winds were much stronger in the 1990s than in the 1960s. Mean decadal air temperatures were above their long-term means throughout the NAFO area with the exception of West Greenland. Indeed, record high decadal means were observed in the Gulf of St. Lawrence (Magdalen Islands) and at Cape Hatteras (southern Middle Atlantic Bight). At most sites, air temperatures have been increasing since the 1960s. Two dominant features of the decadal means are the low temperatures during
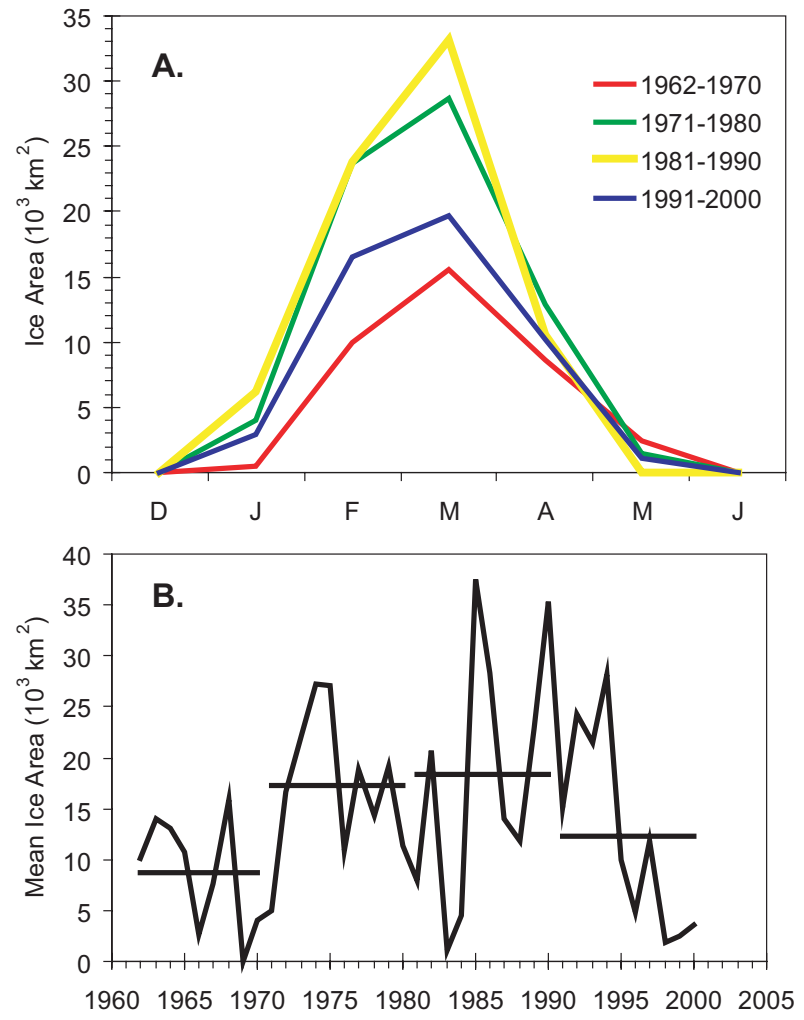

Fig. 12. (A) The monthly mean ice area averaged by decade and (B) the time series of annual mean ice area based upon the average of the monthly means from January to April (bottom) for the Scotian Shelf. The black horizontal lines represent the decadal means.

the late-1800s and early decades of the 1900s throughout the NAFO area and the very warm temperatures in the northern sites, especially on West Greenland, beginning in the 1920s and extending at some sites into the 1970s. Sea-ice conditions off the Labrador and northern Newfoundland coasts, in the Gulf of St. Lawrence and the Scotian Shelf indicate the least amount of ice in the 1960s. From Labrador to the Gulf of St. Lawrence there was little difference in ice severity between the 1970s, 1980s and 1990s, however, on the Scotian Shelf ice area was least during the 1990s compared to the previous two decades. The decadal mean number of icebergs drifting along the Labrador and Newfoundland shelves was at a maximum during the 1990s.

There has been large intra-decadal variability in all variables. High NAO indices, strong northwesterly winds, cold temperatures from the Labrador Sea to the Gulf of Maine and extensive ice cover characterized the early1990s. In 1996, the NAO index experienced its largest 

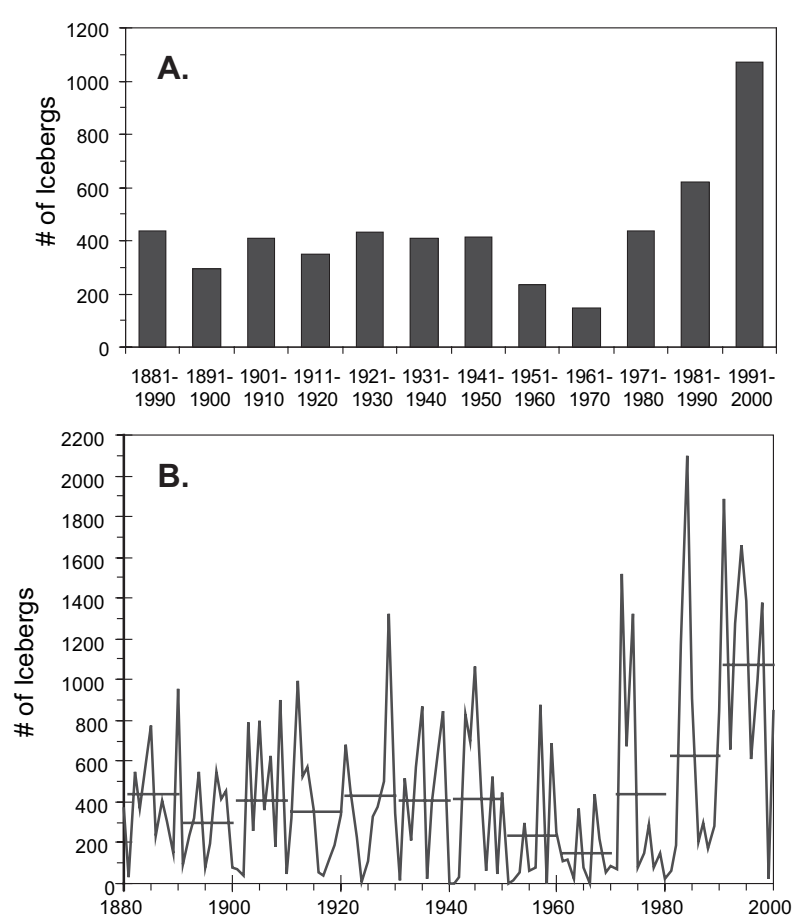

Fig. 13. (A) The decadal means of the number of icebergs crossing south of $48^{\circ} \mathrm{N}$ and (B) the time series of the annual numbers. The horizontal lines in $(\mathbf{B})$ are the decadal means.

annual decline in the over 100-year record. During the remaining years of the decade, the NAO rose achieving values that even exceeded those of the early years of the 1990s. Of significance during the latter half of the decade was the eastward shift in the anomalous pressure fields. In the Northwest Atlantic, the latter half of the decade saw weaker northwesterly winds, warmer temperatures in the Labrador Sea to the Gulf of Maine, and a reduction in sea-ice coverage.

\section{Acknowledgements}

Special thanks to Liam Petrie of the Bedford Institute who helped with the graphics and Roger Pettipas for his support with the data. Thanks also to Lisa Tse for undertaking some of the data analysis. The comments of two anonymous reviewers on an earlier draft of this paper were also appreciated.

\section{References}

BARNSTON, A. G., and R. E . LIVEZEY. 1987. Classification, seasonality, and persistence of low-frequency atmospheric circulation patterns. Mon. Wea. Rev., 115: 1083-1126.

BUCH, E., S. A. PEDERSEN, and M. H. RIBERGAARD. 2004. Ecosystem variability and regime shift in West Greenland waters. J. Northw. Atl. Fish. Sci, 34: 13-28.

COLBOURNE, E. 2004. Decadal changes in the ocean climate in Newfoundland waters from the 1950s to the 1990s. J. Northw. Atl. Fish. Sci, 34: 41-59.

COLBOURNE, E., S. NARAYANAN, and S. PRINSENBERG. 1994. Climatic changes and environmental conditions in the Northwest Atlantic, 1970-1993. ICES Mar. Sci. Symp., 198: $311-322$.

DRINKWATER, K. F. 1996. Climate and oceanographic variability in the Northwest Atlantic during the 1980s and early-1990s. J. Northw. Atl. Fish. Sci., 18: 77-97.

DRINKWATER, K. F., B. PETRIE, and P. C. SMITH. 2003. Climate variability on the Scotian Shelf during the 1990s. ICES Mar. Sci. Symp., 219: 40-49.

DRINKWATER, K. F., R. G. PETTIPAS, G. L. BUGDEN, and P. LANGILLE. 1999. Climatic data for the Northwest Atlantic: a sea ice database for the Gulf of St. Lawrence and the Scotian Shelf. Can. Tech. Rept. Hydrogr. Ocean Sci., 199: 134 p.

HURRELL, J. W. 1995. Decadal trends in the North Atlantic Oscillation: regional temperatures and precipitation. Science, 169: 676-679.

KISTLER, R., E. KALNAY, W. COLLINS, S. SAHA, G. WHITE, J. WOOLLEN, M. CHELLIAH, W. EBISUZAKI, M. KANAMITSU, V. KOUSKY, H.VAN DEN DOOL, R. JENNE, and M. FIORINO. 2001. The NCEPNCAR 50-year reanalysis: monthly means CD-ROM and documentation. Bull. Amer. Meteorolog. Soc., 82: $247-267$.

LILLY, J. M., P. B. RHINES, M. VISBECK, R. DAVIS, J. R. N. LAZIER, F. SCHOOT, and D. FARMER. 1999. Observing deep convection in the Labrador Sea during winter, 19941995. J. Phys. Oceanogr., 29: 2065-2098.

PETERSON, I. K., and S. J. PRINSENBERG. 1990. Sea ice fluctuations in the western Labrador Sea (1963-1988). Can. Tech. Rep. Hydrogr. Ocean Sci., 123: 130 p.

ROGERS, J. C. 1984. The association between the North Atlantic Oscillation and the Southern Oscillation in the Northern Hemisphere. Mon. Wea. Rev., 112: 1999-2015.

SINCLAIR, A., and L. CURRIE. MS 1994. Timing of cod migration into and out of the Gulf of St. Lawrence based on commerical fisheries, 1986-1993. DFO Atl. Fish. Res. Doc., No. 47, 18 p.

STEIN, M. 2004. Climatic overview NAFO Subarea 1, 19912000. J. Northw. Atl. Fish. Sci, 34: 29-40. 